\title{
Estrogen Receptor Beta-Mediated Proliferative Inhibition and Apoptosis in Human Breast Cancer by Calycosin and Formononetin
}

\author{
Jian Chen ${ }^{a, d} \quad$ Xinge Zhao a,d Yu Ye ${ }^{b}$ Yong Wang ${ }^{c}$ Jing Tian ${ }^{c}$ \\ aSchool of Basic Medical Sciences, Guilin Medical University, Guilin, bDepartment of Emergency, First \\ Affiliated Hospital of Guangxi Medical University, Nanning, 'Department of Physiology, School of Basic \\ Medical Sciences, Guilin Medical University, Guilin, China; ' $T$ These authors contributed equally to this \\ paper
}

\section{Key Words}

Calycosin • Formononetin • Breast cancer • Estrogen receptor $\beta$-Insulin-like growth factor 1 receptor $\cdot \operatorname{miR}-375$

\begin{abstract}
Background: Calycosin and formononetin are two main components of isoflavones. In our previous studies, we have respectively reported their antitumor activities on breast cancer cell MCF-7. To further investigate the feasibility of isoflavones in clinically treating breast carcinoma, here we specifically focused on the comparison between calycosin and formononetin, along with the relevant mechanism. Methods: ER-positive (MCF-7, T-47D) and ER-negative breast cancer cells (MDA-231, MDA-435) were respectively treated with calycosin or formononetin. Cell proliferation and apoptosis were measured by MTT assay and flow cytometry. mRNA levels of ER beta $(E R \beta)$ and miR-375 were quantified by real-time PCR. Expression of ER $\beta$ and insulin-like growth factor 1 receptor (IGF-1R), and activation of poly (ADP-ribose) polymerase 1 (PARP-1) were determined by Western blotting. Results: Both calycosin and formononetin impaired proliferation and triggered apoptosis of ER-positive breast cancer cells (MCF-7, T-47D) in a time- and dose-dependent manner, especially in the treatment with calycosin. However, no such effect was observed in ER-negative breast cancer cells, indicating the correlation between isoflavones-induced inhibitory effect and ERs. Thus calycosin and most sensitive MCF-7 cells were used to study the relevant signaling pathway. After the treatment of calycosin, ER $\beta$ expression was significantly increased in MCF-7 cells, followed by decrease of IGF-1R, activation of PARP-1 cleavage and downregulation of miR-375. Conclusion: Calycosin has an advantage on inhibiting breast cancer growth in comparison with formononetin, which is obtained by ERß-mediated regulation of IGF-1R signaling pathways and miR-375 expression.
\end{abstract}




\section{Introduction}

In women, breast cancer represents the most common cancer diagnosis around the world, with average increases of about 2\% [1]. It thus appears urgent to establish new strategies for early detection and effective treatment of breast cancer, so as to alleviate the cancer burden. Fortunately, evidence from studies has confirmed the carcinogenic effects of steroidal estrogens in the development of breast cancer, suggesting the feasibility of antiestrogen therapy in inhibiting tumor malignancy and growth $[2,3]$. Phytoestrogens, a class of plant-derived phenolic compounds, are structurally similar to mammalian estrogens, which determines their abilities to bind to estrogen receptors (ER)- $\alpha$ and ER- $\beta$ and then mimic estrogen effects [4]. Nevertheless, epidemiologic studies reveal that there are fewer breast cancer cases in Asian women than Western women, partially owing to the higher consumption of phytoestrogens from soybean products in Asian countries [5]. The link between phytoestrogens intake and breast cancer prevention show that, after binding to the ERs, phytoestrogens could also exhibit antiestrogenic activity other than estrogenic properties.

Phytoestrogens are subdivided into four main classes: isoflavones, stilbened, lignans, and coumestans [6]. In our previous studies, we have demonstrated that calycosin, a main component of isoflavones, possess anti-carcinogenic activities in human breast cancer cells MCF-7 at relative high concentration ( $\geq 25 \mu \mathrm{M}$ ) [7]. Remarkably, similar anticancer effect was also observed in another typical isoflavones formononetin. We found that formononetin significantly induced apoptosis of MCF-7 cells at concentration higher than $30 \mu \mathrm{M}$ [8]. These results raise the possibility that some phytoestrogens, such as isoflavones, have potential to be clinically used for the prevention of breast cancer carcinogenesis. Therefore, to provide more valuable information about isoflavones-mediated anti-carcinogenic action, here we compared calycosin and formononetin in human breast cancer cells, and investigated the underlying mechanism. In addition, our previous studies mainly focused on the growth and proliferation of ER-positive MCF-7 cells. Considering the diversity and heterogeneity in breast cancer subtypes, another human ER-positive breast cancer cell line T-47D was detected in the present study, with ER-negative breast cancer cells MDA-231 and MDA-435 served as control.

Insulin like growth factor-1 receptor (IGF-1R) is a transmembrane tyrosine kinase receptor, and consist two $\alpha$-chains and two $\beta$-chains [9]. By binding to its ligands, IGF-1 and IGF-2, IGF-1R activates the downstream signaling pathway, thereby contributing to cell proliferation and protection from apoptosis [10]. Previously, we have shown that IGF-1R/ $\mathrm{PI} 3 \mathrm{~K} /$ Akt signaling pathway is involved in formononetin-induced anti-proliferative effects on MCF-7 cells [11]. So we expect the same mechanism to be responsible for inhibition of cell proliferation and apoptosis with treatment of other isoflavones like calycosin.

In brief, the aim of this study was to investigate the effects of isoflavones, calycosin and formononetin, on human breast cancer cells in vitro, together with the possible mechanism. The results demonstrated that both calycosin and formononetin exerted inhibitory effect on ER-positive cells but not ER-negative cells, implying that binding and activation of ER by isoflavones may be involved in its inhibition of breast cancer. Furthermore, decreased IGF-1R expression, reduced miR-375 level and subsequent activation of Poly (ADP-ribose) polymerase 1 (PARP-1) cleavage may act as downstream targets.

\section{Materials and Methods}

\section{Cell culture}

Human breast cancer ER-positive cells (MCF-7, T-47D) and ER-negative cells (MDA-231, MDA-435) were all obtained from ATCC (Manassas, VA, USA). Cells were cultured in RPMI 1640 medium supplemented with $10 \%$ fetal bovine serum (FBS), and incubated at $37^{\circ} \mathrm{C}$ in a humidified atmosphere with $5 \% \mathrm{CO}_{2}$. 
MTT assay

Calycosin $\left(\mathrm{C}_{16} \mathrm{H}_{12} \mathrm{O}_{5}\right)$ was purchased from Phytomarker Ltd (Tianjin, China), and formononetin $\left(\mathrm{C}_{16} \mathrm{H}_{12} \mathrm{O}_{4}\right)$ was purchased from Sigma-Aldrich Ltd (St. Louis, USA). Their stock solution was both prepared by dissolving in dimethyl sulfoxide (DMSO) and stored at $4^{\circ} \mathrm{C}$ for further use. Cell proliferation after treatment of calycosin and formononetin was tested by MTT assay. Four cell lines were seeded into 96-well plates $\left(5 \times 10^{3}\right.$ cells per well) for $12 \mathrm{~h}$, then respectively exposed to various concentrations of calycosin or formononetin $(0,25,50,100 \mu \mathrm{M})$. After 24,48 and $72 \mathrm{~h}$, cells were incubated with 3-[4, 5-dimethylthiazol2-yl]-2, 5-diphenyl tetrazolium bromide (MTT) for 4h and then lysed in DMSO. The optical density (OD) values were measured at 490nm using a plate reader (Bio-Tek Instruments, Winooski, VT, USA).

\section{Flow cytometry assay}

After treatment with calycosin or formononetin $(0,25,50$ and $100 \mu \mathrm{M})$ for $48 \mathrm{~h}$, four cell lines were washed by PBS and stained with Annexin V-fluorescein isothiocyanate (FITC) and propidium iodide (PI) according to the manufacturer's instructions (BD Biosciences, San Diego, CA, USA). Apoptotic cells were detected by a FACS Aria flow cytometer (Becton Dickinson). The early apoptotic cells are Annexin V-FITC positive and PI negative, while late apoptotic cells Annexin V-FITC and PI double-positive.

\section{Real-time PCR assay}

ER-positive MCF-7 cells were treated with calycosin or formononetin (0,25, 50 and $100 \mu \mathrm{M})$ for $48 \mathrm{~h}$. Total RNA from cells was extracted with TRIzol and $10 \mathrm{ng}$ was used for reverse transcription using Revert Aid First Strand cDNA Synthesis Kit (Fermentas, Life Sciences, USA). Next, quantification of ER $\beta$ and miR375 was measured by qRT-PCR with specific primers for ER $\beta$, miR-375, GAPDH and miRNA U6 using SYBR Green qPCR Master Mix (Fermentas, Life Sciences, USA). Here GAPDH and miRNA U6 were respectively used as control to calculate the relative expression level of ER $\beta$ and miR-375.

\section{Western blot assay}

Considering the high similarity between calycosin and formononetin, here more effective calycosin (rather than formononetin) was applied to further investigate the possible mechanism of isoflavones in treating breast cancer. ER-positive MCF-7 cells were incubated with calycosin at concentrations of $0,25,50$ and $100 \mu \mathrm{M}$ for $48 \mathrm{~h}$ or $50 \mu \mathrm{M}$ for $0,12,24,48,72 \mathrm{~h}$. Then the protein samples were separately prepared in a lysis buffer and subjected to sodium dodecyl sulfate-polyacrylamide gel electrophoresis (SDS-PAGE). The separated proteins were transferred onto polyvinylidene difluoride membrane (Millipore, Bedford, MA, USA), followed by blocking with Tris-buffered saline containing 5\% non-fat milk. The proteins of interest were respectively labeled by primary antibodies against ER $\beta$ (1:500; Santa Cruz, CA, USA; catalog number SC-53494), IGF-1R (1:500; Abzoom biolabs, Dallas, TX, USA; catalog number AM3009), PARP-1 (1:1000; Cell Signaling, Danvers, MA, USA; catalog number 9542) and $\beta$-actin (1:1000; Santa Cruz, CA, USA; catalog number sc-47778). Each band intensity was quantified by Image pro plus 5.02 software and normalized to the intensity of endogenous $\beta$-actin band.

\section{Statistical analysis}

Data were represented as mean \pm SD. One-way ANOVA tests was performed using SPSS 12.0 to compare the different treatments. A p-value $<0.05$ was considered statistically significant.

\section{Results}

Inhibited proliferation of ER-positive cells by calycosin and formononetin

To better evaluate the anti-proliferation effect of isoflavones, ER-positive human breast cancer cells (MCF-7, T-47D) and ER-negative cells (MDA-231, MDA-435) were incubated with calycosin or formononetin $(0,25,50,100 \mu \mathrm{M})$ for 24,48 and $72 \mathrm{~h}$. The results showed that both calycosin and formononetin induced time- and dosage-dependent inhibition of proliferation in ER-positive MCF-7 and T-47D cells $(p<0.05)$, indicated as decreasing OD values, as shown in Table 1. However, growth suppression was not observed in ER-negative MDA-231 and MDA-435 cells, which suggested that the two isoflavones suppressed tumor 
Table 1. Anti-proliferative effect of calycosin (CA) and formononetin (FR) in human breast cancer cells detected by MTT assay (mean \pm SD). OD values were obtained from three independent experiments performed in triplicate. Compare with control vehicle $(0 \mu \mathrm{M}) * * p<0.05$

\begin{tabular}{|c|c|c|c|c|c|c|c|c|c|}
\hline & & \multicolumn{2}{|c|}{$\mathrm{Oh}$} & \multicolumn{2}{|c|}{$24 \mathrm{~h}$} & \multicolumn{2}{|c|}{$48 \mathrm{~h}$} & \multicolumn{2}{|c|}{$72 \mathrm{~h}$} \\
\hline & & FR & $\mathrm{CA}$ & FR & $\mathrm{CA}$ & FR & $\mathrm{CA}$ & FR & $\mathrm{CA}$ \\
\hline \multicolumn{10}{|l|}{ MCF-7 } \\
\hline & Control $(0 \mu \mathrm{M})$ & $0.341 \pm 0.018$ & $0.335 \pm 0.021$ & $0.555 \pm 0.022$ & $0.561 \pm 0.024$ & $0.792 \pm 0.024$ & $0.834 \pm 0.024$ & $0.934 \pm 0.017$ & $0.924 \pm 0.021$ \\
\hline & $25 \mu \mathrm{M}$ & $0.333 \pm 0.017$ & $0.331 \pm 0.018$ & $0.501 \pm 0.019^{* *}$ & $0.489 \pm 0.021^{* *}$ & $0.592 \pm 0.029^{* *}$ & $0.555 \pm 0.031^{* *}$ & $0.777 \pm 0.025^{* *}$ & $0.612 \pm 0.023^{* *}$ \\
\hline & $50 \mu \mathrm{M}$ & $0.338 \pm 0.022$ & $0.332 \pm 0.012$ & $0.423 \pm 0.019^{* *}$ & $0.402 \pm 0.022^{* *}$ & $0.501 \pm 0.026^{* *}$ & $0.461 \pm 0.028^{* *}$ & $0.552 \pm 0.027^{* *}$ & $0.473 \pm 0.031^{* *}$ \\
\hline & $100 \mu \mathrm{M}$ & $0.329 \pm 0.021$ & $0.328 \pm 0.019$ & $0.394 \pm 0.021^{* *}$ & $0.343 \pm 0.019^{* *}$ & $0.412 \pm 0.023^{* *}$ & $0.365 \pm 0.023^{* *}$ & $0.391 \pm 0.019^{* *}$ & $0.312 \pm 0.026^{* *}$ \\
\hline \multicolumn{10}{|l|}{$\mathrm{T}-47 \mathrm{D}$} \\
\hline & Control $(0 \mu \mathrm{M})$ & $0.335 \pm 0.019$ & $0.333 \pm 0.013$ & $0.561 \pm 0.019$ & $0.567 \pm 0.014$ & $0.758 \pm 0.021$ & $0.761 \pm 0.024$ & $0.969 \pm 0.025$ & $0.975 \pm 0.028$ \\
\hline & $25 \mu \mathrm{M}$ & $0.328 \pm 0.016$ & $0.329 \pm 0.012$ & $0.532 \pm 0.020$ & $0.502 \pm 0.015^{* *}$ & $0.669 \pm 0.025^{* *}$ & $0.641 \pm 0.021^{* *}$ & $0.821 \pm 0.021^{* *}$ & $0.724 \pm 0.023^{* *}$ \\
\hline & $50 \mu \mathrm{M}$ & $0.332 \pm 0.014$ & $0.323 \pm 0.012$ & $0.459 \pm 0.021^{* *}$ & $0.423 \pm 0.018^{* *}$ & $0.553 \pm 0.028^{* *}$ & $0.523 \pm 0.031^{* *}$ & $0.601 \pm 0.028^{* *}$ & $0.531 \pm 0.022^{* *}$ \\
\hline & $100 \mu \mathrm{M}$ & $0.325 \pm 0.015$ & $0.321 \pm 0.015$ & $0.402 \pm 0.019 * *$ & $0.376 \pm 0.019^{* *}$ & $0.441 \pm 0.027^{* *}$ & $0.405 \pm 0.025^{* *}$ & $0.400 \pm 0.023^{* *}$ & $0.383 \pm 0.026^{* *}$ \\
\hline \multicolumn{10}{|l|}{ MDA-231 } \\
\hline & Control $(0 \mu \mathrm{M})$ & $0.331 \pm 0.017$ & $0.335 \pm 0.022$ & $0.551 \pm 0.020$ & $0.547 \pm 0.022$ & $0.641 \pm 0.025$ & $0.632 \pm 0.028$ & $0.883 \pm 0.021$ & $0.899 \pm 0.029$ \\
\hline & $25 \mu \mathrm{M}$ & $0.329 \pm 0.015$ & $0.338 \pm 0.019$ & $0.527 \pm 0.021$ & $0.513 \pm 0.029$ & $0.611 \pm 0.018$ & $0.603 \pm 0.022$ & $0.862 \pm 0.027$ & $0.854 \pm 0.026$ \\
\hline & $50 \mu \mathrm{M}$ & $0.327 \pm 0.020$ & $0.331 \pm 0.021$ & $0.501 \pm 0.019^{* *}$ & $0.482 \pm 0.021^{* *}$ & $0.568 \pm 0.024^{* *}$ & $0.531 \pm 0.022 * *$ & $0.769 \pm 0.021^{* *}$ & $0.721 \pm 0.031^{* *}$ \\
\hline & $100 \mu \mathrm{M}$ & $0.327 \pm 0.019$ & $0.333 \pm 0.021$ & $0.487 \pm 0.023^{* *}$ & $0.455 \pm 0.016^{* *}$ & $0.512 \pm 0.028^{* *}$ & $0.499 \pm 0.031^{* *}$ & $0.693 \pm 0.024^{* *}$ & $0.679 \pm 0.033^{* *}$ \\
\hline \multicolumn{10}{|l|}{ MDA-435 } \\
\hline & Control $(0 \mu \mathrm{M})$ & $0.328 \pm 0.015$ & $0.333 \pm 0.015$ & $0.532 \pm 0.018$ & $0.551 \pm 0.021$ & $0.655 \pm 0.028$ & $0.651 \pm 0.035$ & $0.899 \pm 0.028$ & $0.888 \pm 0.034$ \\
\hline & $25 \mu \mathrm{M}$ & $0.325 \pm 0.013$ & $0.327 \pm 0.021$ & $0.522 \pm 0.020$ & $0.528 \pm 0.016$ & $0.609 \pm 0.022$ & $0.611 \pm 0.031$ & $0.852 \pm 0.028$ & $0.834 \pm 0.033$ \\
\hline & $50 \mu \mathrm{M}$ & $0.331 \pm 0.018$ & $0.338 \pm 0.022$ & $0.499 \pm 0.019$ & $0.492 \pm 0.022^{* *}$ & $0.555 \pm 0.027^{* *}$ & $0.549 \pm 0.028^{* *}$ & $0.752 \pm 0.019^{* *}$ & $0.733 \pm 0.029^{* *}$ \\
\hline & $100 \mu \mathrm{M}$ & $0.326 \pm 0.017$ & $0.329 \pm 0.019$ & $0.469 \pm 0.250^{* *}$ & $0.474 \pm 0.021^{* *}$ & $0.511 \pm 0.031^{* *}$ & $0.509 \pm 0.035^{* *}$ & $0.701 \pm 0.021^{\text {** }}$ & $0.689 \pm 0.026^{* *}$ \\
\hline
\end{tabular}

Table 2. The percentage of apoptosis in human breast cancer sells after treatment with calycosin (CA) and formononetin (FR) determined by flow cytometry (mean \pm SD). Apoptosis rates were obtained from three independent experiments performed in triplicate. Compare with control vehicle $(0 \mu \mathrm{M}){ }^{* *} \mathrm{p}<0.05$

\begin{tabular}{lcccccccc}
\hline \multirow{2}{*}{ Group } & \multicolumn{2}{c}{ MCF-7 } & \multicolumn{2}{c}{ T-47D } & \multicolumn{2}{c}{ MDA-231 } & \multicolumn{2}{c}{ MDA-435 } \\
& FR & CA & FR & CA & FR & CA & FR & CA \\
\hline Control $(0 \mu \mathrm{M})$ & $2.19 \pm 0.52$ & $2.35 \pm 0.67$ & $2.32 \pm 0.44$ & $2.11 \pm 0.52$ & $2.19 \pm 0.39$ & $2.04 \pm 0.53$ & $2.28 \pm 0.45$ & $2.56 \pm 0.67$ \\
$25 \mu \mathrm{M}$ & $4.99 \pm 0.89$ & $5.34 \pm 1.23$ & $3.45 \pm 0.56$ & $4.68 \pm 0.78$ & $3.12 \pm 0.63$ & $3.21 \pm 1.23$ & $3.43 \pm 0.52$ & $3.42 \pm 0.45$ \\
$50 \mu \mathrm{M}$ & $10.17 \pm 0.92^{* *}$ & $15.88 \pm 1.45^{* *}$ & $8.11 \pm 0.22^{* *}$ & $11.92 \pm 1.34^{* *}$ & $3.89 \pm 0.76$ & $3.78 \pm 1.09$ & $4.16 \pm 0.67$ & $4.63 \pm 0.91$ \\
$100 \mu \mathrm{M}$ & $21.33 \pm 0.77^{* *}$ & $28.67 \pm 0.99^{* *}$ & $15.21 \pm 0.82^{* *}$ & $20.29 \pm 1.21^{* *}$ & $4.03 \pm 0.56$ & $4.11 \pm 0.89$ & $5.21 \pm 0.32$ & $4.59 \pm 1.01$ \\
\hline
\end{tabular}

cell growth through regulation of ER-mediated signaling pathway. Moreover, we found that calycosin caused stronger inhibition of cell proliferation compared to formononetin, especially in MCF-7 cells.

\section{Increased apoptosis of ER-positive cells by calycosin and formononetin}

Consistent with results from MTT assay, both calycosin and formononetin promoted apoptosis of MCF-7 and T-47D cells in a dosage-dependent manner, leading to obvious increase in the percentage of early apoptotic cells $(p<0.05)$ (Table 2). Similarly, calycosin displayed greater proapoptotic function than formononetin in the same ER-positive cell lines. And after treatment of calycosin, MCF-7 cells always exhibited higher apoptotic rate than T-47D cells. On the contrary, there was no significant change in MDA-231 and MDA435 cells treated with calycosin or formononetin. The increased apoptosis of ER-positive cells further confirmed the involvement of ER activation in isoflavones-mediated growth regulation of breast cancer cells.

Regulation of ER $\beta$ and miR-375 in MCF-7 cells by calycosin and formononetin

Based on results from MTT assay and flow cytometry assay, we chose the most drugsensitive MCF-7 cells to study the possible mechanism for isoflavones-induced growth 
Table 3. Expression of ER $\beta$ and miR-375 after treatment with calycosin (CA) and formononetin (FR) determined by real-time PCR (mean \pm SD). Data were obtained from three independent experiments performed in triplicate. Compare with control vehicle $(0 \mu \mathrm{M}))^{* *} p<0.05$

\begin{tabular}{lcccc}
\hline \multicolumn{1}{c}{ Group } & \multicolumn{2}{c}{ ERß/GAPDH } & \multicolumn{2}{c}{ miR-375/U6 } \\
& FR & CA & FR & CA \\
\hline Control $(0 \mu \mathrm{M})$ & $0.521 \pm 0.032$ & $0.521 \pm 0.032$ & $1.034 \pm 0.032$ & $1.034 \pm 0.032$ \\
$25 \mu \mathrm{M}$ & $0.563 \pm 0.043$ & $0.753 \pm 0.082^{* *}$ & $1.023 \pm 0.037$ & $0.988 \pm 0.032$ \\
$50 \mu \mathrm{M}$ & $9.012 \pm 0.056^{* *}$ & $1.032 \pm 0.061^{* *}$ & $0.792 \pm 0.031^{* *}$ & $0.721 \pm 0.041^{* *}$ \\
$100 \mu \mathrm{M}$ & $1.004 \pm 0.072^{* *}$ & $1.267 \pm 0.055^{* *}$ & $0.612 \pm 0.024^{* *}$ & $0.511 \pm 0.052^{* *}$ \\
\hline
\end{tabular}

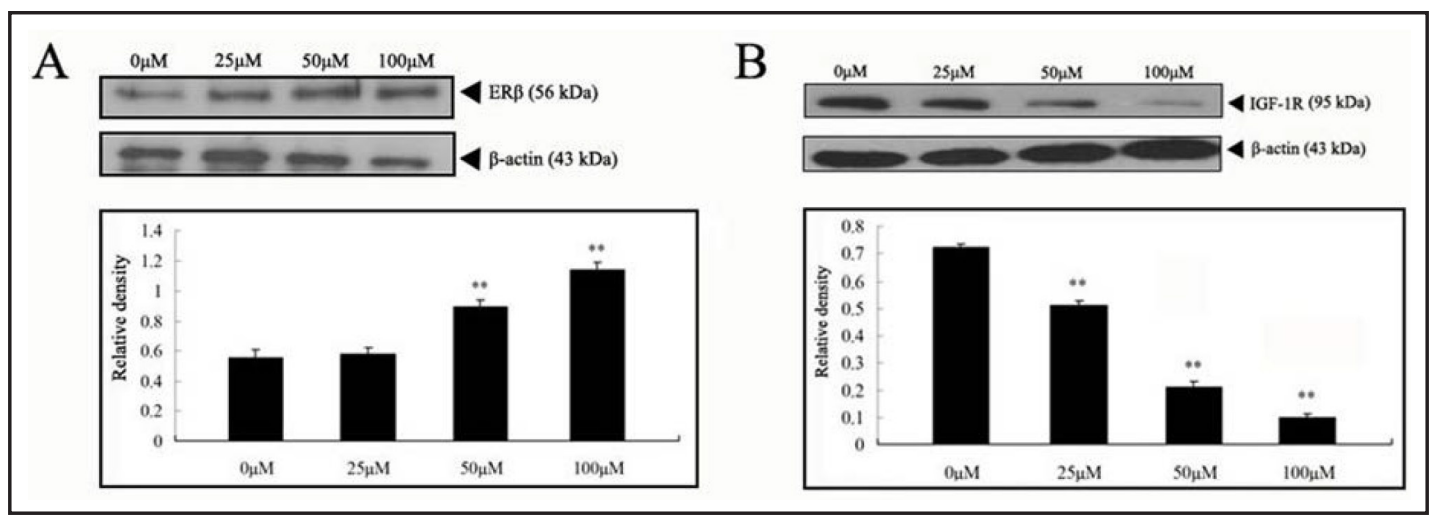

Fig. 1. Upregulated ER $\beta$ (A) and inhibited IGF-1R (B) expression in MCF-7 cells by calycosin. Cells were treated with various concentrations of calycosin $(0,25,50,100 \mu \mathrm{M})$ for $48 \mathrm{~h}$, and then protein samples were labeled with specific antibodies against ER $\beta$ and IGF-1R. The same blots were probed with anti- $\beta$-actin antibody as a loading standard. Results are representative of three independent experiments performed in triplicate. ${ }^{* *} \mathrm{p}<0.05$ versus control vehicle $(0 \mu \mathrm{M})$.

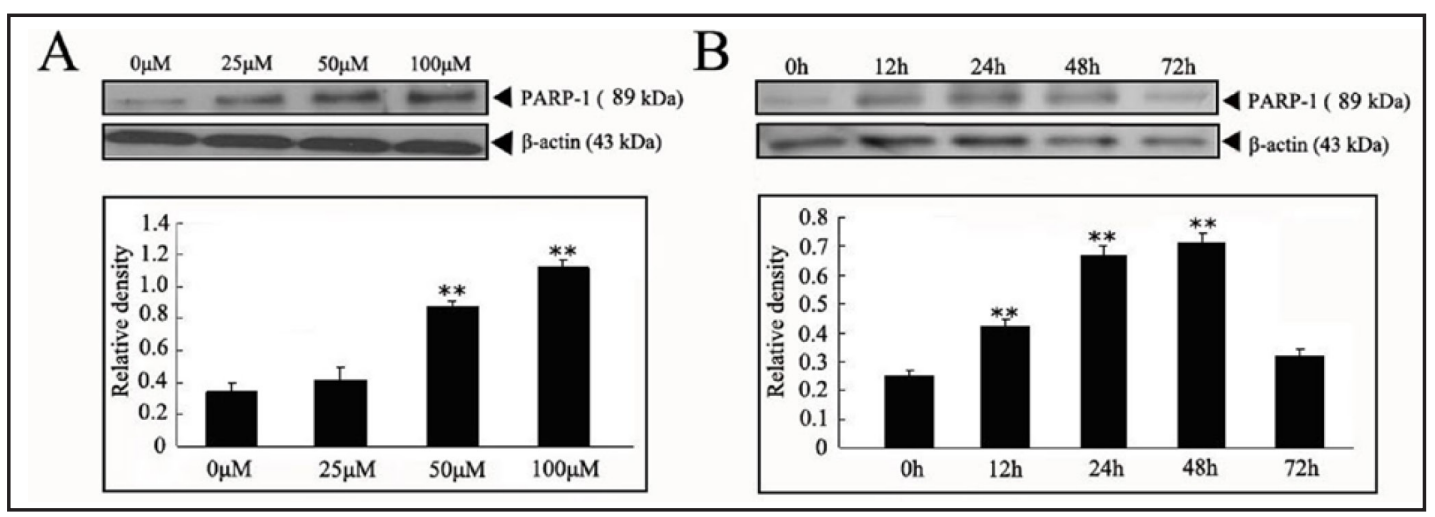

Fig. 2. Activated PARP-1 cleavage in MCF-7 cells by calycosin. Cells were treated with $0,25,50,100 \mu \mathrm{M}$ calycosin for $48 \mathrm{~h}(\mathrm{~A})$, or $50 \mu \mathrm{M}$ for $0,12,24,48,72 \mathrm{~h}(\mathrm{~B})$. The cleaved PARP-1 in MCF-7 cells was determined by Western blot, with $\beta$-actin served as loading controls. Results are representative of three independent experiments performed in triplicate. ${ }^{* *} \mathrm{p}<0.05$ versus control vehicle $(0 \mu \mathrm{M}$ or $0 \mathrm{~h})$.

inhibition and apoptosis of breast cancer cells. The results showed that calycosin and formononetin gradually upregulated expression levels of ER $\beta$ but downregulated expression levels of miR-375, which was again more obvious in calycosin-treated MCF-7 cells $(p<0.05)$, as shown in Table 3.

Activation of ER $\beta$ and inactivation of IGF-1R in MCF-7 cells by calycosin

After detection of ER $\beta$ mRNA levels in MCF-7 cells, the levels of ER $\beta$ protein with treatment of calycosin $(0,25,50$ and $100 \mu \mathrm{M})$ were determined by Western blot assay. We 
found that, in accordance with mRNA data, calycosin significantly increased ER $\beta$ expression in a dosage-dependent manner when compared with $0 \mu \mathrm{M}$ control vehicle $(p<0.05)$, as shown in Figure 1A. Meanwhile, the highest levels of IGF-1R were showed in untreated MCF-7 cells, whereas calycosin significantly reduced its expression $(p<0.05)$, especially at the highest concentration $(100 \mu \mathrm{M})$ (Fig. 1B).

Induction of PARP-1 cleavage in MCF-7 cells by calycosin

During cell apoptosis process, cleavage of PARP-1 by caspases is considered as an important hallmarker. When MCF-7 cells were treated with $0,25,50$ and $100 \mu \mathrm{M}$ calycosin for $48 \mathrm{~h}$ or $50 \mu \mathrm{M}$ calycosin for $0 \mathrm{~h}, 12 \mathrm{~h}, 24 \mathrm{~h}, 48 \mathrm{~h}$ and $72 \mathrm{~h}$, it was found that levels of cleaved PARP-1 time- and dosage-dependently increased $(p<0.05)$, which suggests that activation of PARP-1 cleavage is involved in calycosin-madiated cell apoptosis, as shown in Figure 2A and Figure 2B. The reduced PARP-1 cleavage at $72 \mathrm{~h}$ may be caused by gradual decline in concentration of calycosin.

\section{Discussion}

Calycosin and formononetin are two main components of isoflavones that have been attracting attention for their possible anti-cancer effects. Previously, we have separately reported that both of them significantly inhibited proliferation and induced apoptosis in human breast cancer MCF-7 cells at relative high concentration. Based on these findings, we here further observed and compared the anti-proliferation effect between calycosin and formononetin, so as to provide more valuable information in evaluating the feasibility of their clinical application. The results demonstrated that although the two isoflavones successfully decreased cell proliferation and triggered apoptosis in ER-positive cells MCF-7 and T-47D, the inhibitory effects on the same cell line were found greater in treatment of calycosin versus formononetin, implying that calycosin may be superior to formononetin in treating human breast cancer.

However, the specific mechanism associated with isoflavones-mediated antiproliferation remains unclear. It is reported that the increase in circulating estrogen accounts for development of breast cancer, and the interaction between estrogen and ERs partially contributes to estrogen-mediated tumor growth [12]. Accordingly, regulation of ERs may be a promising target for treating estrogen-dependent breast cancer. In present study, not only ER-positive but ER-negative breast cancer cell lines were observed after treatment of calycosin and formononetin. We found that the two isoflavones both exerted anti-proliferation effects against ER-positive MCF-7 and T-47D, while there was no change in cell proliferation and apoptosis for ER-negative MDA-231 and MDA-435. Therefore, we concluded that calycosin and formononetin may exhibit anticancer properties through ERdependent mechanism.

Until now, more and more studies have proved the function of ER $\alpha$ in malignancies, as well as the antagonistic relationship between ER $\alpha$ and ER $\beta$ in modulating the development of breast cancer $[13,14]$. We then determined ER $\beta$ expression respectively at mRNA and protein levels. As expected, treatment with calycosin and formononetin significantly enhanced ER $\beta$ mRNA levels in a dosage-dependent manner. In addition, there was corresponding increase in the synthesis of ER $\beta$ protein after treatment of calycosin, again confirming that upregulation of ER $\beta$ plays a major role in isoflavones-mediated inhibition of ER-positive breast cancer.

IGF-1R signaling could control cell growth and participate in the development of normal tissues and malignancy $[15,16]$. At present, epidemiological studies have correlated increased IGF-1 serum levels with risk of breast cancer, so inhibition of IGF-1R signaling can serve as new target for breast cancer therapy $[17,18]$. Especially, Tang et al. reported that estrogen activated the IGF-1R signaling through ER $\beta$ in lung cancer and finally promoted A549 cell proliferation [19]. In agreement with their observation, we here demonstrated that, subsequent to calycosin-induced upregulation of ER $\beta$, the expression of IGF-1R gradually 
declined. It means that the correlation of ER $\beta$ and IGF-1R signaling pathway also exists in ER-positive breast cancer, which could be regulated by isoflavones.

Activation of caspase cascades, including cleavage of some key proteins, is considered responsible for cell apoptosis [20]. One of those substrates is PARP-1 that could be cleaved by caspase-3 into $89-\mathrm{kD}$ and $24-\mathrm{kD}$ fragments. And 24-kD PARP-1 fragment can block DNA repair, finally leading to cell death [21]. Hence cleaved PARP-1 is considered as apoptotic markers. We investigated whether activation of PARP-1 cleavage occurred during isoflavonesinduced cell apoptosis. The results showed that next to ER $\beta$-mediated IGF-1R decline, there was increased cleavage of PARP-1 with the treatment of calycosin in a time- and dosedependent manner, indicating the participation of PARP-1.

On the other hand, compelling studies have demonstrated that Micro RNAs (miRNAs), a class of small non-coding RNA, have a major impact on cell growth and differentiation by regulating gene expression at posttranscriptional level $[22,23]$. Simonini et al. reported that miR-375 was expressed highly in breast cancer cells MCF-7, and there existed a positive loop between ER $\alpha$ and miR-375 [24]. Notably, our study revealed that along with reduced ER $\beta$ levels, the miR-375 expression dose-dependently decreased with treatment of calycosin. Based on these data, we hypothesize that a negative loop between ER $\beta$ and miR-375 may also be available in breast cancer cells, which could be strengthened by isoflavones. Nonetheless, further research was needed to confirm this hypothesis.

In a word, our study proved the anti-tumor activity of calycosin and formononetin, the two main isoflavones, in ER-positive breast cancer cells, even though the effect was somewhat weak for formononetin. Meanwhile, this anti-proliferative effect was achieved by upregulated ER $\beta$-mediated IGF-1R inhibition, PARP- 1 cleavage activation and miR-375 decrease. Depending on these results, it can be predicted that isoflavones is a promising alternative for clinical therapy of breast cancer.

\section{Acknowledgements}

This research was supported by grants from National Natural Science Foundation of China (N0.81260343).

\section{Reference}

1 Bray F, Jemal A, Grey N, Ferlay J, Forman D: Global cancer transitions according to the Human Development Index (2008-2030): a population-based study. Lancet Oncol 2012;13:790-801.

2 Królik M, Milnerowicz H: The effect of using estrogens in the light of scientific research. Adv Clin Exp Med 2012;21:535-543.

3 Liang J, Shang Y: Estrogen and cancer. Annu Rev Physiol 2013;75:225-240.

-4 Chen KI, Erh MH, Su NW, Liu WH, Chou CC, Cheng KC: Soyfoods and soybean products: from traditional use to modern applications. Appl Microbiol Biotechnol 2012;96:9-22

5 Mense SM, Hei TK, Ganju RK, Bhat HK: Phytoestrogens and breast cancer prevention: possible mechanisms of action. Environ Health Perspect 2008;116:426-433.

6 Lin AH, Li RW, Ho EY, Leung GP, Leung SW, Vanhoutte PM, Man RY: Differential ligand binding affinities of human estrogen receptor- $\alpha$ isoforms. PLoS One 2013;8:e63199.

7 Tian J, Duan YX, Bei CY, Chen J: Calycosin induces apoptosis by upregulation of RASD1 in human breast cancer cells MCF-7. Horm Metab Res 2013;45:593-598.

$\checkmark 8$ Chen J, Sun L: Formononetin-induced apoptosis by activation of Ras/p38 mitogen-activated protein kinase in estrogen receptor-positive human breast cancer cells. Horm Metab Res 2012;44:943-948. 
9 Pollak M: The insulin and insulin-like growth factor receptor family in neoplasia: an update. Nat Rev Cancer 2012;12:159-169.

10 Zhao Y, Wang Z, Jiang Y, Yang C: Inactivation of Rac1 reduces Trastuzumab resistance in PTEN deficient and insulin-like growth factor I receptor overexpressing human breast cancer SKBR3 cells. Cancer Lett 2011;313:54-63.

11 Chen J, Zeng J, Xin M, Huang W, Chen X: Formononetin induces cell cycle arrest of human breast cancer cells via IGF1/PI3K/Akt pathways in vitro and in vivo. Horm Metab Res 2011;43:681-686.

12 Kang NH, Hwang KA, Lee HR, Choi DW, Choi KC: Resveratrol regulates the cell viability promoted by $17 \beta$-estradiol or bisphenol A via down-regulation of the cross-talk between estrogen receptor $\alpha$ and insulin growth factor-1 receptor in BG-1 ovarian cancer cells. Food Chem Toxicol 2013;59:373-379.

13 Grober OM, Mutarelli M, Giurato G, Ravo M, Cicatiello L, De Filippo MR, Ferraro L, Nassa G, Papa MF, Paris O, Tarallo R, Luo S, Schroth GP, Benes V, Weisz A: Global analysis of estrogen receptor beta binding to breast cancer cell genome reveals an extensive interplay with estrogen receptor alpha for target gene regulation. BMC Genomics 2011;12:36.

14 Renoir JM, Marsaud V, Lazennec G: Estrogen receptor signaling as a target for novel breast cancer therapeutics. Biochem Pharmacol 2013;85:449-465.

-15 Worralti C, Nedelcu D, Serly J, Suleymanova N, Oprea I, Girnita A, Girnita L: Novel mechanisms of regulation of IGF-1R action: functional and therapeutic implications. Pediatr Endocrinol Rev 2013;10:473-484.

-16 Xue M, Cao X, Zhong Y, Kuang D, Liu X, Zhao Z, Li H: Insulin-like growth factor-1 receptor (IGF-1R) kinase inhibitors in cancer therapy: advances and perspectives. Curr Pharm Des 2012;18:2901-2913.

17 Sabbatini P, Rowand JL, Groy A, Korenchuk S, Liu Q Atkins C, Dumble M, Yang J, Anderson K, Wilson BJ, Emmitte KA, Rabindran SK, Kumar R: Antitumor activity of GSK1904529A, a small-molecule inhibitor of the insulin-like growth factor-I receptor tyrosine kinase. Clin Cancer Res 2009;15:3058-3067.

18 Ma CX, Suman VJ, Goetz M, Haluska P, Moynihan T, Nanda R, Olopade O, Pluard T, Guo Z, Chen HX, Erlichman C, Ellis MJ, Fleming GF: A phase I trial of the IGF-1R antibody Cixutumumab in combination with temsirolimus in patients with metastatic breast cancer. Breast Cancer Res Treat 2013;139:145-153.

19 Tang H, Liao Y, Chen G, Xu L, Zhang C, Ju S, Zhou S: Estrogen upregulates the IGF-1 signaling pathway in lung cancer through estrogen receptor- $\beta$. Med Oncol 2012;29:2640-2648.

20 Gupta S, Kass GE, Szegezdi E, Joseph B: The mitochondrial death pathway: a promising therapeutic target in diseases. J Cell Mol Med 2009;13:1004-1033.

21 Sukhanova MV, Khodyreva SN, Lavrik OI: Influence of poly(ADP-ribose) polymerase-1 and its apoptotic 24$\mathrm{kD}$ fragment on repair of DNA duplexes in bovine testis nuclear extract. Biochemistry (Mosc) 2006;71:736748.

22 Harquail J, Benzina S, Robichaud GA: MicroRNAs and breast cancer malignancy: an overview of miRNAregulated cancer processes leading to metastasis. Cancer Biomark 2012;11:269-280.

23 Rivas MA, Venturutti L, Huang YW, Schillaci R, Huang TH, Elizalde PV: Downregulation of the tumorsuppressor miR-16 via progestin-mediated oncogenic signaling contributes to breast cancer development. Breast Cancer Res 2012;14:R77.

24 de Souza Rocha Simonini P, Breiling A, Gupta N, Malekpour M, Youns M, Omranipour R, Malekpour F, Volinia S, Croce CM, Najmabadi H, Diederichs S, Sahin O, Mayer D, Lyko F, Hoheisel JD, Riazalhosseini Y: Epigenetically deregulated microRNA-375 is involved in a positive feedback loop with estrogen receptor $\alpha$ in breast cancer cells. Cancer Re 2010;70:9175-9184. 